https://doi.org/10.18778/1509-877X.2021.01.01

\title{
OPODATKOWANIE NIEPOŻĄDANEJ SPOŁECZNIE KONSUMPCJI. WPROWADZENIE DO TEMATYKI
}

\begin{abstract}
Streszczenie. Współcześnie można zaobserwować zjawisko wprowadzania do systemów podatkowych wielu państw podatków od towarów i usług uznanych za społecznie niepożądane. Należą one do kategorii podatków akcyzowych. Ich przedmiotem jest niezdrowa żywność - przede wszystkim napoje orzeźwiające z dodatkiem cukru, dania nasycone tłuszczem, środkami utrwalającymi smak, generalnie: jedzenie śmieciowe. W Polsce podatkiem tego rodzaju jest obowiązujący od 2021 r. podatek cukrowy. Artykuł poświęcony jest zarysowaniu organizacyjnych i prawnych aspektów funkcjonowania tej kategorii podatków oraz konsekwencji ich funkcjonowania, a zwłaszcza możliwości wpływania na skalę niepożądanej konsumpcji i jej ograniczania ze względu na potrzeby ochrony zdrowia społeczeństwa.
\end{abstract}

Słowa kluczowe: prawo podatkowe, opodatkowanie, podatek „od grzechu”, podatek cukrowy

\section{ZAGADNIENIA POJĘCIOWO-TERMINOLOGICZNE}

Towary i usługi niebudzące pozytywnych skojarzeń społecznych, takie jak napoje alkoholowe, wyroby tytoniowe czy karty używane m.in. do gier hazardowych, są od wielu wieków przedmiotem odrębnego opodatkowania.

* Profesor nauk prawnych, Uniwersytet Jagielloński (emeritus), e-mail: bogumil. brzezinski@uj.edu.pl, https://orcid.org/0000-0003-3923-5627 
Podatki od wybranych towarów nazywane są akcyzami. Chociaż nazwa „akcyza” pojawiła się w Europie ok. 1600 r., to tradycja takich podatków jest starsza. Niekiedy funkcję akcyzy spełnia podwyższone opodatkowanie określonych towarów w ramach ogólnego podatku od sprzedaży.

W Polsce ideologia nakładania podatków czy opłat od niepożądanej społecznie konsumpcji - albo inaczej: „prozdrowotnych” bądź „proekologicznych" - nie została dotąd poddana szerszej analizie. Stąd uzasadnione wydaje się sięgnięcie do tego źródła wiedzy, jakim jest literatura obca, zwłaszcza krajów anglosaskich. Argumenty pro i contra prezentowane są tam w nad wyraz wyczerpujący sposób.

Autorzy anglosascy $\mathrm{z}$ upodobaniem nazywają podatki od towarów i usług, których konsumpcja nie jest rekomendowana ze względów społecznych, terminem sin taxes (podatki „od grzechu”). Typowe sin taxes to akcyzy od wyrobów alkoholowych czy wyrobów tytoniowych. Jest to określenie efektowne, ale mało precyzyjne, i to co najmniej z dwóch powodów.

Po pierwsze, w etyce judeochrześcijańskiej konsumpcja napojów alkoholowych jako taka nie ma negatywnych konotacji i nie jest uważana za grzech. Świadczą o tym fragmenty Ewangelii, w których prowadzenie działalności gospodarczej w postaci winnicy uznawane jest za etycznie neutralne (a celem tej działalności raczej nie była sprzedaż soku $\mathrm{z}$ winogron) ${ }^{1}$. Jeszcze bardziej oczywiste staje się to w kontekście pierwszego cudu dokonanego przez Jezusa, który przecież nie zamieniał wina w wodę, ale odwrotnie $^{2}$. Ewangeliczny opis Ostatniej Wieczerzy dopełnia tego obrazu ${ }^{3}$. Jeżeli konsumpcja napojów alkoholowych miałaby być grzechem w świetle judeochrześcijańskich kanonów etycznych, to jedynie w sytuacjach sporego ich nadużywania przez jednostkę lub gdyby używanie napojów alkoholowych zagrażało bezpieczeństwu konsumenta bądź osób trzecich.

Ale i ta teza może być podana w wątpliwość w świetle starotestamentowego opisu historii Noego (uznanego za pierwszego plantatora winorośli), który upił się do nieprzytomności własnymi wyrobami (co pośrednio świadczyć może o ich dobrej jakości). Odium nieuporządkowania moralnego spada mianowicie w tej historii nie na leżącego w namiocie, pijanego i roznegliżowanego w nieprzystojny sposób ojca, ale na jego syna, Chama,

\footnotetext{
1 Mt 20, 1-16.

2 J 2, 1-12.

3 Łk 22, 17-18, 20; Mt 26, 27; Mk 14, 23, 25.
} 
który wstrząśnięty tym widokiem pobiegł po swoich braci, zamiast - jak sugeruje tekst - okryć najpierw tatusia czymkolwiek ${ }^{4}$.

Sugestię, że wino ma zbawienny wpływ na zdrowie, a zwłaszcza prowadzi do długowieczności (Noe żył 950 lat $^{5}$ ), należy, chociaż z żalem - w świetle dosyć jednoznacznych ustaleń współczesnej medycyny - odrzucić. Należy jednak brać pod uwagę, że badania prowadzone w ramach tej samej, współczesnej medycyny wykazały, iż picie niewielkich ilości czerwonego wina może w rzeczywistości być korzystne dla zdrowia, zmniejszając ryzyko chorób serca, udaru mózgu czy demencji ${ }^{6}$. To samo da się powiedzieć o marihuanie, która pełnić może zarówno funkcje narkotyzujące, jak i lecznicze $e^{7}$

Po drugie, zakres podatków zaliczanych do sin taxes jest w piśmiennictwie - zwłaszcza amerykańskim - rozszerzany współcześnie poprzez etykietowanie $\mathrm{w}$ taki sposób także podatków od konsumpcji towarów innych niż klasyczne używki, poczynając od tzw. niezdrowej żywności (ang. unhealthy food) - tłuszczów, żywności nadmiernie przetworzonej, wyrobów zawierających cukier, przez plastikowe torebki, talerze czy sztućce, na solariach i klubach ze striptizem kończąc ${ }^{8}$. W konsekwencji można sformułować postulat przyjęcia konwencji nazewniczej, zgodnie z którą zasadne jest używanie określenia „podatki od niepożądanej (ze społecznego punktu widzenia) konsumpcji” albo szerzej, jak u niektórych autorów anglosaskich, „podatki od zachowań społecznie niepożądanych” (ang. socially undesirable behaviors) ${ }^{9}$.

Z tym też można by było dyskutować, stawiając pytanie, czy konsumpcja określonej kategorii towarów i usług jest niepożądana ze względu na jakieś obiektywne przesłanki, czy raczej w społeczeństwie bądź w przeważającej jego części jedynie panuje przekonanie, że jest ona szkodliwa, czy wreszcie jest tak, że to politycy, w poszukiwaniu nowych źródeł dochodów

${ }_{4} \operatorname{Rdz} 9,20-27$.

$5 \mathrm{Rdz}$ 9, 29.

${ }^{6} \mathrm{O}$ medycznym zastosowaniu wina na przestrzeni wieków, aż do współczesności, pisze zajmująco Ph. Norrie, The History of Wine as a Medicine: From its Beginnings in China to the Present Day, Cambridge 2019.

7 Zob. R. Abuhasira, L. Bar-Lev Schleider, R. Mechoulam, V. Novack, Epidemiological Characteristics, Safety and Efficacy of Medical Cannabis in the Elderly, „European Journal of Internal Medicine" 2018, March, t. 49, s. 44 i n.

8 Zob. F. Liu, Sin Taxes: Have Governments Gone Too Far in Their Efforts to Monetize Morality, „Boston College Law Review” 2018, nr 2, s. 777.

9 Zob. ibidem, s. 786. 
publicznych, dekretują szkodliwość społeczną pewnych kategorii towarów i usług. Operując nazwą zbiorczą podatków od niepożądanej konsumpcji, trzeba zdawać sobie sprawę z pewnego stopnia jej konwencjonalności.

W literaturze anglojęzycznej podatki od napojów z dodatkiem cukru, jako pewna kategoria podatków od niezdrowej żywności, noszą dosyć często nazwę soda taxes ${ }^{10}$. Nazwa ta także nie grzeszy precyzją, gdyż sugeruje opodatkowanie wszystkich napojów gazowanych, podczas gdy podatki te dotyczą napojów gazowanych słodzonych, a niekiedy także niegazowanych. W tym ostatnim przypadku chodzi raczej o opodatkowanie plastikowej butelki, a nie wody, która się w niej znajduje.

\section{Tak zWAna opŁata cukrowa w Polsce}

W Polsce od 2021 r. obowiązuje danina publiczna o nazwie „opłata cukrowa”. Wprowadzono ją Ustawą z dnia 14 lutego 2020 r. o zmianie niektórych ustaw $\mathrm{w}$ związku $\mathrm{z}$ promocją prozdrowotnych wyborów konsumentów ${ }^{11}$. Stosowne przepisy znalazły się ostatecznie $\mathrm{w}$ Ustawie $\mathrm{z}$ dnia 11 września 2015 r. o zdrowiu publicznym ${ }^{12}$ (art. 12a-12k).

Warto dokonać oceny „opłaty cukrowej” z punktu widzenia teorii prawa podatkowego - tak aby ustalić jej założenia i charakter prawny tego nowego w Polsce tworu prawa daninowego, natomiast objętość artykułu skłania do istotnej kondensacji analizy charakteru ekonomicznego i prawnego „opłaty cukrowej” i sformułowania na wstępie kilku tez.

Po pierwsze, wbrew zastosowanej przez ustawodawcę nazwie, „opłata cukrowa" jest podatkiem. Ma ona wszystkie teoretyczne cechy podatku - jest daniną bezzwrotną, przymusową, ogólną, nieodpłatną i uiszczaną w formie pieniężnej. W szczególności brak odpłatności dla podmiotów zobowiązanych do wnoszenia „opłaty cukrowej” dyskwalifikuje stosowanie tej nazwy na oznaczenie nowej daniny publicznej. Spełnia też ona kryteria uznania za podatek na potrzeby stosowania do niej przepisów Ordynacji podatkowej zgodnie z art. $2 \$ 1$ pkt 1 tej ustawy ${ }^{13}$.

10 Zob. np. L. Cedeno, Global Implementation of Soda Taxes: Is There a Better Solution for Combatting Obesity?, „Brooklyn Journal of International Law” 2019, t. 45, nr 1, s. 329 i n.; C. Kaplan, Big Soda: Too Sweet to Fail, „Fordham Urban Law Journal” 2017, t. 44, nr 4, s. 1267 i n.

11 Dz.U. z 2020 r., poz. 1492.

12 Dz.U. z 2021 r., poz. 1292 ze zm.

13 Tekst jedn. Dz.U. z 2020 r., poz. 1325 ze zm. 
Nazwy „opłata cukrowa” użyto według wszelkiego prawdopodobieństwa ze względów politycznych, jako że wcześniej miały miejsce polityczne deklaracje (zwłaszcza przedwyborcze), że nowy układ polityczny „nie będzie podnosić podatków”. Deklaracje kategorycznego sprzeciwu wobec ewentualnych prób podnoszenia podatków - a tym bardziej wprowadzania nowych - składał też kandydat na Prezydenta RP, a obecnie urzędujący Prezydent RP, Andrzej Duda. Natomiast o opłatach - zarówno cukrowej, jak i jakiejkolwiek innej - nie było wówczas mowy.

Praktyka maskowania charakteru prawnego podatków przez stosowanie dla danin publicznych nazw nieadekwatnych do ich materialnych cech była charakterystyczna dla okresu PRL, gdzie np. podatek dochodowy od przedsiębiorstw państwowych nosił nazwę: wpłaty z zysku, a podatek od posiadania środków trwałych - oprocentowanie środków trwałych. Te naiwne i prymitywne w istocie rzeczy zwyczaje nazewnicze wracają, a klinicznym przykładem manipulacji nazewniczych jest właśnie „opłata cukrowa”.

To wszystko uzasadnia - dopóki nie rozważa się treści obowiązujących przepisów prawa - posługiwanie się adekwatnym dla tej daniny publicznej w Polsce określeniem „podatek cukrowy” ${ }^{14}$.

Po drugie, podatek cukrowy, konstrukcja prawna znana w wielu państwach świata, należy do grupy podatków akcyzowych. Podatek akcyzowy to - w ujęciu encyklopedycznym - „podatek konsumpcyjny kwalifikowany jednocześnie jako podatek obrotowy, obciążający czynności dotyczące niektórych towarów lub usług" ${ }^{15}$. W podatku cukrowym przedmiotem opodatkowania jest wprowadzenie do obrotu artykułów spożywczych, do których w procesie produkcji dodano cukier. Podobnie jak inne akcyzy, podatek ten jest jednofazowym podatkiem obrotowym. Tego rodzaju podatki nazywane są też niekiedy podatkami od dochodu wydatkowanego, a to na podstawie triady: podatek dochodowy od dochodu uzyskiwanego, od dochodu zmaterializowanego (od majątku) i od dochodu wydatkowanego (od konsumpcji). Taki podział może jednak budzić rozmaite zastrzeżenia.

14 Próby tłumaczenia przez niektórych autorów wspomnianego wyżej defektu pojęciowo-terminologicznego przez odwołanie się do definicji podatku w art. 3 ust. 3 Ordynacji podatkowej, w myśl którego jeżeli w ustawie (Ordynacji podatkowej) jest mowa o podatku, rozumie się przez to również opłaty, nie zasługują nawet na polemikę. Zob. T. Janicki, N. Kociak, Opłata cukrowa w interpretacjach Dyrektora Krajowej Informacji Skarbowej, „Przegląd Podatkowy” 2021, nr 10, s. 5.

15 Hasło Akcyza, [w:] Wielka encyklopedia prawa, t. 11: Prawo finansowe, Warszawa 2017, s. 75. 
Po trzecie, opodatkowanie spożycia cukru może mieć miejsce w drodze zastosowania rozmaitych technik podatkowych. I tak opodatkować można produkcję roślin, z których cukier jest wytwarzany. Opodatkować można produkcję/sprzedaż cukru jako towaru. Opodatkować też można wytwarzanie/sprzedaż wyrobów zawierających cukier. Gdyby uznać, że za opodatkowaniem konsumowanego ostatecznie cukru leżą jakieś fiskalne bądź pozafiskalne racje, to wybór jednej spośród tych technik będzie elementem polityki podatkowej.

Powyższe nie wyczerpuje zresztą wszystkich możliwości nakładania podwyższonego obciążenia podatkowego na - ogólnie rzecz ujmując - konsumpcję cukru: można wyobrazić sobie obciążenie podatkowe urządzeń służących do wytwarzania wyrobów cukierniczych lub z użyciem cukru. Nie musi to być odrębny podatek - wystarczyłoby np. prawne wyłączenie możliwości amortyzowania takich urządzeń dla celów podatkowych. Można też opodatkować/podwyższyć opodatkowanie reklam wyrobów zawierających nadmierną ilość cukru etc., etc.

Niezależnie od zastosowanej techniki podatkowej, każdy z tych sposobów podwyższenia obciążenia podatkowego wyrobów zawierających cukier prowadzi do wzrostu obciążenia konsumpcji tych towarów. Podatnikami podatku cukrowego będą podmioty zajmujące się wytwarzaniem cukru lub wyrobów zawierających cukier, ale ciężar podatku w całości bądź w znacznej części poniosą konsumenci wspomnianych towarów ze względu na działanie mechanizmu przerzucania podatku. Im mniejsza elastyczność popytu na dany rodzaj towarów, tym większa skala przerzucania podatku, zawartego, w sensie ekonomicznym, w cenie wyrobów, na konsumentów. Trzeba przy tym zastrzec, że podatnikiem podatku cukrowego nie jest konsument wyrobów z zawartością cukru. Nie ma też żadnych podstaw do określania konsumentów jako podatników „rzeczywistych” - w odróżnieniu od podatników „formalnych”, jakimi mieliby być wspomniani producenci czy też sprzedaw$\mathrm{cy}^{16}$. W kategoriach prawnych podatnikiem jest jedynie podmiot spełniający kryteria definicyjne z art. 7 Ordynacji podatkowej.

Po czwarte, wprowadzenie podatku cukrowego motywowane jest zazwyczaj celem niefiskalnym, jakim jest przeciwdziałanie niekorzystnym skutkom zdrowotnym nadmiernego spożycia cukru. Te skutki są odczuwalne zarówno w wymiarze indywidualnym (pogorszenie stanu zdrowia

16 Zob. B. Brzeziński, Prawo podatkowe. Zagadnienia teorii i praktyki, Toruń 2017, s. $175-176$. 
poszczególnych jednostek), jak i ogólnospołecznym (koszty zmniejszenia wydajności i leczenia osób nadużywających wyrobów z zawartością cukru). Dla podkreślenia owych niefiskalnych aspektów podatku cukrowego nierzadko łączy się go z ukierunkowaniem strumienia środków pozyskanych tą drogą na cele prewencji i usuwania skutków nadmiernego spożywania wyrobów zawierających cukier bądź - w ostateczności - innych celów społecznych uznawanych za ważne (np. z zakresu szeroko pojętej ochrony zdrowia). Jest to, ogólnie rzecz biorąc, obliczone na obłaskawienie mniej wyrobionych intelektualnie odłamów społeczeństwa i uzyskanie ich akceptacji dla nowego podatku.

Po piąte, wiele problemów stwarzać może sprecyzowanie przedmiotu opodatkowania. Nie ma bowiem w żadnym systemie podatkowym podatku od cukru w ogóle, ale są podatki od wyrobów z dodatkiem cukru, np. od napojów z zawartością cukru. W tym ostatnim przypadku prawodawca musi dokonać licznych wyborów, np. czy opodatkować wyroby, które z natury mają sporą zawartość cukru (sok jabłkowy), czy też może tylko te, w których cukier znalazł się w trakcie procesu produkcji. Dalej - czy wysokość podatku uzależnić od absolutnej zawartości cukru w produkcie czy od nadwyżki ponad określony poziom itp., itd.

Można by było zbadać, jak wprowadzenie podatku cukrowego uzasadniono w Polsce w projekcie omawianej ustawy. Z punktu widzenia nauki prawa podatkowego takie działanie byłoby z gruntu bezproduktywne, gdyż kwestia rozbieżności między treścią ustawy podatkowej a treścią jej uzasadnienia, z jednej strony, oraz dostrzegalnymi gołym okiem rozbieżnościami między treścią uzasadnień ustaw podatkowych a ogólnymi kierunkami polityki społecznej i gospodarczej, z drugiej, jest tak oczywista (i to nie od dzisiaj), że powinna być raczej przedmiotem zainteresowania specjalistów z dziedziny nauk politycznych, a zwłaszcza marketingu politycznego czy psychologii społecznej.

\section{NOWA ERA PODATKÓW OD NIEPOŻĄDANEJ KONSUMPCJI}

W dyskursie politycznym na przestrzeni czasu obserwuje się zmianę w sposobie motywowania wprowadzania i podwyższania podatków od niepożądanej społecznie konsumpcji. Początkowo podatki takie tłumaczono istnieniem potrzeb budżetowych; z czasem - i ma to miejsce także współcześnie - zaczęto akcentować moralny wymiar tych podatków, stawiając na pierwszym miejscu uzasadnienie etyczne takich operacji i prezentując 
jednocześnie wysoki poziom paternalizmu ${ }^{17}$. Takie deklaracje są jednak mało przekonujące, dlatego że możliwe jest wykazanie zbieżności w czasie działań w sferze wspomnianego opodatkowania $\mathrm{z}$ rosnącymi problemami budżetowymi państwa czy władz lokalnych ${ }^{18}$.

Współcześnie można mówić o nowej erze podatków od niepożądanej społecznie konsumpcji ${ }^{19}$. Potencjalnie przyczyną rozrostu tego sektora opodatkowania mogą być bądź względy fiskalne, bądź względy prozdrowotne czy proekologiczne. Wnikanie w to, co było wyłącznym bądź przeważającym motywem wprowadzenia tego rodzaju podatku, wydaje się mijać z celem. W Stanach Zjednoczonych w ostatnim dziesięcioleciu można zaobserwować gwałtowny wzrost podatków od niepożądanej konsumpcji na wszystkich szczeblach systemu władzy, można wręcz mówić o nowej erze takiego opodatkowania, w ramach którego występują tradycyjne podatki od alkoholu i wyrobów tytoniowych, a jednocześnie system podatkowy jest wzbogacany o rozmaite inne podatki od niepożądanej konsumpcji ${ }^{20}$.

Wyrażane są godne uwagi poglądy, w myśl których prawodawca, mając w perspektywie możliwość stworzenia nowych źródeł dochodów, nie waha się udostępniać - znosząc zakazy czy też ograniczenia - szerszej publiczności produkty bądź usługi, których sprzedaż była dotąd uznana za społecznie niepożądaną ${ }^{21}$.

Nie sposób nie dostrzec zjawiska o zupełnie odmiennym wektorze. Otóż tak jak podstawową przyczyną zniesienia prohibicji w Stanach Zjednoczonych w latach trzydziestych XX w. była potrzeba pozyskania większych dochodów z akcyzy ${ }^{22}$, tak współcześnie obserwowana w wielu stanach tego kraju liberalizacja przepisów dotyczących gier hazardowych, marihuany czy halucynogennych grzybków także wpisana jest w kontekst oczekiwania na powstanie dodatkowych źródeł dochodów podatkowych.

Wdzięcznym polem rozwoju sin taxes w szerokim rozumieniu jest współcześnie wzrost znaczenia problematyki ochrony środowiska, a w szczególności

17 Zob. R.H. Perkins, Salience and Sin: Designing Taxes in the New Sin Era, „Brigham Young University Law Review” 2014, nr 1, s. 151.

18 Ibidem, s. 152.

19 Zob. F. Liu, Sin Taxes..., s. 779.

20 Zob. R.H. Perkins, Salience and Sin..., s. 146.

${ }^{21}$ Ibidem, s. 156-157.

22 Zob. L.V. Harrison, E. Laine, After Repeal: A Study of Liquor Control Administration, New York-London 1936, s. 173. 
ochrony klimatu. Pojawiła się odrębna w pewnym sensie kategoria podatków środowiskowych (ang. green taxes), obejmujących produkcję i świadczenie usług społecznie (klimatycznie, środowiskowo etc.) niepożądanych ${ }^{23}$. Przykładowo chodzi tu o emisję gazów cieplarnianych, używanie plastikowych toreb na zakupy, jednorazowych plastikowych talerzy i sztućców w punktach gastronomicznych, plastikowych butelek na wodę itp.

W Stanach Zjednoczonych paliwa dla polityki podatkowej, w ramach której rozwija się ideologia podatków od niepożądanej konsumpcji, dostarcza niekwestionowana i dostrzegalna przez przeciętnego obywatela sytuacja rozpowszechniania się w społeczeństwie plagi otyłości, w związku z którą ponadnormatywna otyłość dzieci, młodzieży i osób w średnim wieku jest realnym problemem zdrowotnym, i to zarówno w kategoriach zdrowia publicznego, jak i w kategoriach finansowych wyzwań stojących przed narodowym systemem ochrony zdrowia.

Zwolennicy przeciwdziałania otyłości metodami podatkowymi podkreślają, że nieprawidłowa dieta prowadzi do otyłości i rozmaitych chorób o przewlekłym charakterze, dlatego złe wybory żywieniowe powodują powstawanie kosztów opieki zdrowotnej, które obciążają także osoby niewykazujące cech otyłości. Powołując się na poglądy A. Pigou, akcentują oni potrzebę internalizacji kosztów społecznych nadużyć żywieniowych i przeniesienia ich na tych, którzy te koszty prokurują ${ }^{24}$. Podatki podnoszące ceny wyrobów to najprostsza i najbardziej efektywna metoda, która temu może służyć 25 .

Zwolennicy podatku od żywności zwanej niekiedy „śmieciową”, prowadzącej do otyłości w społeczeństwie, uważają więc, że podatki od słodzonych napojów gazowanych lub „śmieciowej” żywności są jedynym rozwiązaniem pozwalającym kontrolować rosnące koszty ochrony zdrowia wywołane tym zjawiskiem.

Wszystko to daje asumpt do stwierdzenia, że kwestie zdrowotne czy też ekologiczne stają się dla polityków okazją - być może niepowtarzalną w średnim horyzoncie czasowym - podwyższania poziomu opodatkowania przy stosunkowo słabym oporze społecznym. To ostatnie determinowane jest ogólnie przychylnym nastawieniem społecznym wobec kwestii moralności. Niezależnie od intencji decydentów nowe podatki tej kategorii

${ }^{23}$ W Polsce problematykę tę przedstawił po raz pierwszy J. Głuchowski, Podatki ekologiczne, Warszawa 2002.

${ }^{24}$ Zob. F. Liu, Sin Taxes..., s. 773.

25 Zob. R.H. Perkins, Salience and Sin..., s. 177. 
są skutecznym czynnikiem pacyfikującym opór podatkowy w społeczeństwie. O tym, że jest to rodzaj gry politycznej, świadczy chociażby prosta konstatacja, że rozmaite cele prozdrowotne czy proekologiczne można byłoby $\mathrm{z}$ powodzeniem sfinansować ze środków osiągniętych z podwyższenia podatku dochodowego czy podatku od sprzedaży towarów i usług. Względy stricte polityczne skłaniają jednak do przeprowadzenia operacji bardziej skomplikowanej, w postaci nowych podatków, co „wzbogaca” system podatkowy nie tylko o nowe regulacje prawne, ale też o całą otoczkę ich funkcjonowania, włącznie z problemami interpretacyjnymi i dodatkowymi obowiązkami formalnymi nakładanymi na podatników.

Przy projektowaniu podatków od niepożądanej konsumpcji jednym z głównych problemów jest ustalenie optymalnego ciężaru podatkowego, jaki będzie ostatecznie spadać na konsumentów tych towarów lub usług. Bierze się bowiem pod uwagę to, że poziom obciążenia podatkowego wpływa znacząco na reakcję podatników na nałożenie podatku bądź też podniesienie podatku w formie dotychczas istniejącej ${ }^{26}$.

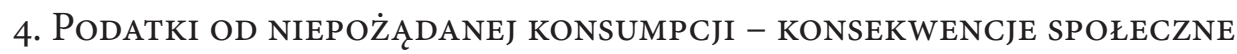

Sporym problemem zwiększenia poziomu obciążenia towarów akcyzowych bądź objęcia podatkiem towarów lub usług dotychczas nieobjętych szczególnym opodatkowaniem jest skala negatywnych konsekwencji takiej operacji. Mogą one mieć charakter zarówno fiskalny, jak i pozafiskalny. Do negatywnych konsekwencji fiskalnych można zaliczyć spadek - co najmniej czasowy - wpływów z podatku już istniejącego, m.in. na skutek zmniejszenia konsumpcji towarów objętych podatkiem. Wynika to po części z poszukiwania i znajdowania substytutów określonych towarów, które są opodatkowane na poziomie niższym bądź w ogóle nieopodatkowane, dalej z wytwarzania towarów przez konsumentów we własnym zakresie oraz z przemytu towarów z innych jurysdykcji podatkowych ${ }^{27}$.

Przemyt na większą lub mniejszą skalę może mieć charakter zorganizowany, ale można też mówić o quasi-przemycie polegającym na wielokrotnym przekraczaniu granicy $\mathrm{z}$ towarem - w dozwolonych prawem

${ }^{26}$ Ibidem, s. 151.

$27 \mathrm{Z}$ informacji dostępnych w środkach masowego przekazu wynika, że w Portugalii po wprowadzeniu podatku od napojów z podwyższoną zawartością cukru pojawił się przemyt tego rodzaju napojów z innych krajów Unii Europejskiej. 
ilościach - zakupionym w kraju sąsiadującym. Różnice cenowe wynikające $z$ różnych poziomów opodatkowania takich samych wyrobów skłaniają ponadto obywateli kraju, w którym opodatkowanie jest wyższe (i znajduje zauważalny wyraz w cenie wyrobów), do zakupu podczas pobytu za granicą dopuszczalnej do przywozu przepisami celnymi ilości towarów o niższej niż we własnym kraju cenie.

Oddzielnym problemem jest kwestia społecznej akceptacji podatków od niepożądanej konsumpcji. Będzie ona zapewne różna w różnych społeczeństwach i w odniesieniu do różnych przedmiotów konsumpcji, a także skali ich opodatkowania bądź podniesienia wysokości opodatkowania. Należy przy tym odróżnić kwestię kształtowania się ogólnej oceny tego rodzaju operacji podatkowych (opinia publiczna) od kwestii realnych, rzeczywistych reakcji poszczególnych jednostek na podwyższone opodatkowanie. Na dodatek inna może być reakcja deklarowana, zwłaszcza przed wprowadzeniem podatku bądź jego podwyższeniem, a inna reakcja rzeczywista - już po wprowadzeniu podatku lub jego podwyższeniu.

Złożoność sytuacji, które powinny być poddawane ocenie przy projektowaniu podatku od niepożądanej społecznie konsumpcji, nie czyni z niej zagadnienia wyjętego z obszaru badań naukowych. Tutaj prym wiedzie nauka amerykańska - zachowania konsumentów przed i po zmianach w wysokości opodatkowania to jeden ze znaczących tematów badań amerykańskich ekonomistów i socjologów nad podatkami konsumpcyjnymi. $\mathrm{W}$ innych krajach także uwidacznia się zainteresowanie zasadami racjonalnej konstrukcji „nowych” podatków, a zwłaszcza podatku cukrowego ${ }^{28}$.

Ze wspomnianych badań dotyczących omawianej tu grupy podatków wynika, że skłonność do ich akceptacji jest większa w sytuacji, gdy są one „skalibrowane” na umiarkowanym poziomie, gdy przychody z ich funkcjonowania przeznaczane są na potrzeby ograniczania niepożądanej konsumpcji bądź na usuwanie jej skutków albo na promowanie alternatyw konsumpcyjnych, czy też w ostateczności na wspieranie działań mających ogólnie pozytywne konotacje w odczuciu społecznym. Inaczej mówiąc, stopień społecznej akceptacji dla opodatkowania niepożądanej konsumpcji rośnie, gdy jest ono powiązane $\mathrm{z}$ innymi działaniami, np. z przeznaczeniem pozyskiwanych środków na akceptowalne cele, bądź z działaniami

${ }_{28}$ Zob. obszerna i bardzo kompetentnie przygotowana analiza rozmaitych aspektów budowy i funkcjonowania podatku cukrowego w kontekście możliwości zapobiegania otyłości w: S. Duckett, H. Swerissen, A Sugary Drinks Tax: Recovering the Community Costs of Obesity, Grattan Institute, November 2016. 
niezwiązanymi z kwestiami podatkowymi, np. z wprowadzeniem obowiązku wyraźnego oznaczania przez producentów wyrobów szkodliwych dla zdrowia, włącznie ze specyfikacją ilości szkodliwych substancji w jednostce wyrobu.

Immanentną i nieusuwalną wadą podatków od niepożądanej społecznie konsumpcji - podobnie zresztą jak i od wszystkich podatków od sprzedaży i świadczenia usług - jest ich regresywny charakter ${ }^{29}$. Wyraża się to $\mathrm{w}$ tym, że podwyższenie w konsekwencji opodatkowania poziomu cen standardowej konsumpcji (zwłaszcza żywności) jest bardziej odczuwalne przez osoby o niższych dochodach, gdyż ich rozporządzalne zasoby finansowe, determinowane poziomem bieżących dochodów, spadają (po opodatkowaniu) w relatywnie większym stopniu niż osób o wyższych dochodach $^{30}$. Prowadzi to do pogłębienia nierówności sytuacji materialnej i pogorszenia położenia biedniejszych w porównaniu z bogatszymi, co nie jest ani społecznie, ani politycznie pożądane.

Dodatkowo dzieje się tak, że podatki od niepożądanej społecznie konsumpcji nakładane są na towary, na które popyt jest względnie mało elastyczny $^{31}$. Oznacza to, że ciężar opodatkowania konsumentów tej kategorii podnosi się z dwóch powodów: przez dodatkowe opodatkowanie, a ponadto przez trudności w rezygnacji z dotychczasowych nawyków konsumpcyjnych, a więc ograniczonych praktycznie możliwości rezygnacji z konsumpcji opodatkowanych towarów. To powoduje, że przy założeniu, iż dochody konsumenta są stabilne, podatek cukrowy (i podobne) po części ogranicza konsumpcję niezdrowej żywności, ale - w krótkim okresie - ogranicza także inne wydatki, np. prozdrowotne.

Można spotkać pogląd, zgodnie z którym regresywność opodatkowania jest niezgodna $z$ ogólną, uznawaną wręcz za podstawową, zasadą systemu opodatkowania - zasadą nakładania podatków odpowiednio do zdolności do zapłaty podatku ${ }^{32}$. Nie sposób jednak nie zauważyć, że konsument opodatkowanego towaru może być (i z reguły jest) nim obciążony, ale trudno chyba twierdzić, że podatek został na tegoż konsumenta „nałożony”.

29 Zob. B. Brzeziński, Prawo podatkowe..., s. 176.

30 Rezultaty badań nad stopniem regresywności podatku od napojów sztucznie słodzonych przedstawiają H. Allcott, B.B. Lockwood, D. Taubinsky, Regressive Sin Taxes, with an Application to the Optimal Soda Tax, „The Quarterly Journal of Economics” 2019, t. 134, nr 3, s. 1557 i n.

${ }^{31}$ Zob. R.H. Perkins, Salience and Sin..., s. 143 i n.

32 Zob. F. Liu, Sin Taxes..., s. 779. 
Paradoksalnie, niektórzy autorzy dostrzegają w regresywności podatków od niepożądanej społecznie konsumpcji ich zaletę - regresywność wzmacnia bowiem funkcję „perswazyjną” takich podatków. Im bardziej znaczący finansowo podatek, tym większy jego wpływ na zachowanie (tu - pożądane ograniczenie konsumpcji) konsumenta ${ }^{33}$. To „perswazyjne” oddziaływanie podatku sięga poza pole relacji między państwem a podatnikami, gdyż konsumenci nie są w tym przypadku - co trzeba ponownie podkreślić - podatnikami. Jest więc pewnym paradoksem to, że regresywny charakter podatków może zwiększyć ich efektywność, ponieważ osoby osiągające niskie dochody mogą być bardziej wrażliwe na zmiany cen niż ogół populacji ${ }^{34}$.

Jeżeli w tej sytuacji w opodatkowaniu można się doszukiwać pożądanego bodźca do zmiany nawyków konsumpcyjnych, to nie odpowiada to w pełni realiom - przynajmniej jeśli chodzi o osoby należące do uboższych warstw społeczeństwa. Mają one zazwyczaj utrwalone nawyki konsumpcyjne i towarzyszącą temu niską świadomość alternatyw konsumpcyjnych. Na dodatek - jak to pokazują badania amerykańskie - osoby takie z przyczyn ekonomicznych są częściej niż inni upośledzone komunikacyjnie, a w związku z tym korzystają z lokalnych, peryferyjnie położonych sklepów, oferujących zazwyczaj żywność niezdrową (przesyconą cukrem i tłuszczem), bo na taką znajdują najwięcej konsumentów, a ich właścicieli nie stać ani organizacyjnie, ani finansowo na rozszerzenie asortymentu o towary z gatunku zdrowej żywności.

Stąd też pomysły - jak dotąd mało skonkretyzowane - aby efekty zapobiegawcze osiągać przy wykorzystaniu konstrukcji podatku dochodowego, ale nie płaconego przez konsumentów, lecz przez producentów niezdrowej żywności ${ }^{35}$.

5. WNIOSKI

Podatki od towarów, których konsumpcja uważana jest za niepożądaną społecznie, cieszą się na świecie sporą i wciąż rosnącą popularnością. Umacnia ją możliwość uzasadniania ich pobierania względami prozdrowotnymi

${ }^{33}$ Zob. R.F. Mann, Controlling the Environmental Costs of Obesity, „Environmental Law" 2017, nr 3, s. 777.

34 Zob. D. Schenk, Exploiting the Salience Bias in Designing Taxes, „Yale Journal on Regulation" 2011, t. 28, nr 2, s. 296.

35 Zob. R.F. Mann, Controlling..., s. 777. 
i odwoływania się w związku z tym do argumentów z zakresu ochrony zdrowia publicznego. Argumentacja ta jest na tyle atrakcyjna, że podatki tego rodzaju nie budzą większego oporu społecznego. Na dodatek są to podatki pośrednie, nieodczuwane bezpośrednio przez podmioty będące ich ekonomicznym - a nie prawnym - adresatem. To powoduje, że podatki te (często kamuflowane dodatkowo etykietą opłaty) stają się niezwykle atrakcyjnym narzędziem presji fiskalnej i zwiększania przychodów publicznych. Możliwość sięgania po te „nisko wiszące owoce” jest na tyle kusząca, że prowadzi do zamykania oczu zarówno na społecznie niekorzystne skutki wzrostu regresywności opodatkowania, jak i na możliwość stosowania alternatywnych, pozapodatkowych sposobów obniżania poziomu spożycia cukru i innych niekorzystnie oddziałujących na zdrowie substancji ${ }^{36}$.

Trzeba podkreślić, że rosnący opór społeczny wobec opodatkowania powoduje konieczność poszukiwania takich pól eksploatacji podatkowej społeczeństwa, na których działania podatkowe władz spotkają się ze stosunkowo niewielką krytyką czy oporem. Takim polem wydaje się obecnie obszar podatków od społecznie niepożądanej konsumpcji ${ }^{37}$.

W piśmiennictwie zwraca się uwagę na rosnące koszty lobbingu związanego $\mathrm{z}$ typowaniem produktów żywnościowych do kategorii niezdrowych oraz określaniem parametrów, których przekroczenie ma być kryterium poddania wyrobów opodatkowaniu. Nie da się ukryć tego, że cukier obecny jest zarówno w soku jabłkowym i napojach taki sok zawierających, jak i w rozmaitych napojach nazywanych energetyzującymi, orzeźwiającymi itp. Wprowadzenie podatku cukrowego już na starcie stawia w lepszej sytuacji rynkowej producentów butelkowanej wody niż producentów napojów wysokocukrowych. Tych ostatnich dotknąć może też zróżnicowanie opodatkowania, np. ze względu na pochodzenie cukru w wyrobach (napoje słodkie naturalnie versus napoje dosładzane) lub ze względu na stężenie cukru. To samo może dotyczyć tłuszczów, utrwalaczy smaku etc., etc.

Wszystko to stwarza olbrzymie pole do gry lobbingowej i reklamowej, prowadzonej w celu uzyskania lepszej niż konkurencja pozycji w zakresie opodatkowania, zużywającej - mało efektywnie ze społecznego punktu widzenia - zasoby materialne i finansowe.

Trzeba zauważyć, że szkody społeczne wywołane konsumpcją niezdrowej żywności mają inny charakter niż te powodowane nadmierną konsumpcją

36 Zob. F. Liu, Sin Taxes..., s. 789.

37 Zob. R.H. Perkins, Salience and Sin..., s. 153. 
alkoholu i wyrobów tytoniowych. Skutki nadużywania cukru czy innych składników niezdrowej żywności dotyczą nadużywających, innych zaś osób jedynie w niewielkim stopniu. Są to co najwyżej członkowie rodzin (ze względu na konieczność opieki nad osobą schorowaną), ale już nie, tak jak w przypadku papierosów, osoby postronne, które, same nie paląc tytoniu, zapadają na rozmaite choroby wywołane dymem tytoniowym. Odpada tu więc argument narażania innych niż konsumenci wyrobów z nadmiarem cukru czy tłuszczu na negatywne skutki zjawiska nadmiernej konsumpcji niezdrowej żywności. Osoby z otyłością nie są też, co do zasady - w przeciwieństwie np. do alkoholików - groźne dla otoczenia.

Wracając jeszcze do anglosaskiej kategorii pojęciowej sin taxes - staje się coraz bardziej widoczne, że współcześnie sprawdzają się one jako narzędzia zwiększania dochodów publicznych (budżetowych). Dzieje się tak po części przynajmniej dlatego, że „adresowane” są one do ludzi uboższych, mniej wykształconych, uzależnionych w większym lub mniejszym stopniu od pomocy społecznej, a nakładane są na towary o względnie niewielkiej elastyczności popytu. I taka sytuacja, na którą osoby obciążone podatkiem nie mają zazwyczaj większego wpływu, jest głównym ich "grzechem”.

Wykorzystywanie haseł moralnych dla podwyższania opodatkowania rodzi nieuchronnie pytanie o moralność postępowania prawodawcy. Przykład amerykański prowadzi do wniosku, że to prawodawcy na różnych szczeblach systemu władzy stają się uzależnieni od idei stosowania sin taxes. Paradoksalnie moralny aspekt tej sytuacji przesuwa się z moralnej oceny produktów i usług objętych opodatkowaniem (a katalog tych produktów i usług nieustannie jest rozszerzany) na ocenę rzetelności dialogu władzy ze społeczeństwem. Sin taxes stają się coraz częściej grzeszne nie ze względu na ocenę moralną korzystania z niepożądanych społecznie dóbr i usług, ale ze względu na deficyt prawdy w tłumaczeniu przez władzę publiczną społeczeństwu potrzeby wprowadzania nowych podatków tego rodzaju.

\section{BibLIOGRAFiA}

Abuhasira R., Bar-LevSchleider L., Mechoulam R., Novack V., Epidemiological Characteristics, Safety and Efficacy of Medical Cannabis in the Elderly, „European Journal of Internal Medicine" 2018, March, t. 49.

Allcott H., Lockwood B.B., Taubinsky D., Regressive Sin Taxes, with an Application to the Optimal Soda Tax, „The Quarterly Journal of Economics” 2019, t. 134, nr 3.

Brzeziński B., Prawo podatkowe. Zagadnienia teorii i praktyki, Toruń 2017. 
Cedeno L., Global Implementation of Soda Taxes: Is There a Better Solution for Combatting Obesity?, „Brooklyn Journal of International Law” 2019, t. 45, nr 1.

Duckett S., Swerissen H., A Sugary Drinks Tax: Recovering the Community Costs of Obesity, Grattan Institute, November 2016.

Głuchowski J., Podatki ekologiczne, Warszawa 2002.

Harrison L.V., Laine E., After Repeal: A Study of Liquor Control Administration, New YorkLondon 1936.

Hasło Akcyza, [w:] Wielka encyklopedia prawa, t. 11: Prawo finansowe, Warszawa 2017.

Janicki T., Kociak N., Opłata cukrowa w interpretacjach Dyrektora Krajowej Informacji Skarbowej, „Przegląd Podatkowy” 2021, nr 10.

Kaplan C., Big Soda: Too Sweet to Fail, „Fordham Urban Law Journal” 2017, t. 44, nr 4.

Liu F., Sin Taxes: Have Governments Gone Too Far in Their Efforts to Monetize Morality, „Boston College Law Review” 2018, nr 2.

Mann R.F., Controlling the Environmental Costs of Obesity, „Environmental Law” 2017, nr 3.

Norrie Ph., The History of Wine as a Medicine: From its Beginnings in China to the Present Day, Cambridge 2019.

Perkins R.H., Salience and Sin: Designing Taxes in the New Sin Era, „Brigham Young University Law Review" 2014, nr 1.

Schenk D., Exploiting the Salience Bias in Designing Taxes, „Yale Journal on Regulation” 2011 , t. 28 , nr 2 .

\section{TAXation of SOCIALly Undesirable CONSUMption. An INTRODUCTION}

Summary. Nowadays, one can observe the phenomenon of introducing into the tax systems of many countries taxes on goods and services considered socially undesirable. They belong to the category of excise duties. Their subject is unhealthy food - mainly refreshing drinks with sugar added, fatty meals, flavor enhancers etc. (junk food). In Poland, this type of tax is the sugar tax applicable from the beginning of 2021. The article is devoted to the organizational and legal aspects of the functioning this category of taxes and the consequences of their functioning, especially the possibility of influencing the scale of undesirable consumption and its reduction due to the needs of protecting the health of the society.

Keywords: tax law, taxation, sin tax, sugar tax 